\title{
Subvenção a instituições religiosas e a Constituição federal de 1946.
}

\author{
Ataliba Nogueira \\ Catedrático de Teoria Geral do Estado na \\ Faculdade de Direito da Universidade de
São Paulo.
}

O exmo. e revmo. sr. dom Hugo Bressane de Araujo, arcebispo-bispo de Marília, dêste Estado, pede-me parecer sôbre os fundamentos do veto do sr. prefeito municipal, que negou sancção ao projeto de lei de auxílio monetário. ao seminário diocesano de São Pio $\mathrm{X}$.

Basta que considere o primeiro e máximo argumento: o da sua inconstitucionalidade. Seria ele intransponível e trancaria tôda e qualquer oportunidade para a decretação da medida, ao passo que os demais motivos invocados pelo sr. prefeito se referem a possiveis violações de leis ordinárias, o que poderia ser sanado, se preciso, com facilidade, pelo legislativo municipal.

Trata-se, pois, de interpretar texto constitucional, o que não é fácil, tanto mais que se não pode limitar a tomar certas palavras de todo um artigo e nem mesmo a analisar um único artigo, arrancado de texto longo, que, por sua vez, é obra de elaboração política, histórica e jurídica. Não é tarefa tão simples como parece, ainda que a suposição seja a de que a lei deva ser entendida pelo povo, uma vez que a ninguém é lícito ignorar-lhe os preceitos. Examinamos, em seu inteiro teor, a longa motivação do veto, mas, pela razão apontada, limitamo-nos à unica indagação:

- E constitucional o ato legislativo ou executivo que concede auxílio a instituições religiosas? 
Quando agiu bem a câmara municipal de Marília: ao votar a lei ou ao aprovar o veto?

E constitucional o projeto de lei que concede auxílio ao seminário?

1. Sob o aspecto da sua constitucionalidade, nada há que opôr. $O$ nosso regime político não é ateu, nem poderia desconhecer os sentimentos do povo brasileiro. Longe de nós afirmarmos que o regime se distancia do povo e que adotou a pretenciosa posição de que êle se eleva acima do povo para deixá-lo em plano secundário, com as suas crenças e culto religioso, pelos quais consequentemente haveria de revelar-se indiferente.

Não é isto que se lê na constituição de 18 de setembro de 1946, da qual foram proscritos o ateismo, o agnosticismo, o laicismo e o indiferentismo religioso. Pelo contrário, logo no preâmbulo, coloca o nome de Deus como soberano senhor do povo e do Brasil, sendo lógico que sòmente esta invocação liminar já está mostrando que lhe reconhece a necessidade de culto por parte dos brasileiros.

Proibiu, sim, o regalismo e o padroado, qualquer forma de estado protetor da religião ou - o que quase é o mesmo - estado usurpador dos seus direitos; proibiu que seja instituidor de culto religioso, ou aliado de determinada religião ou igreja. Do contrário, incidiria no grave êrro de confundir os poderes civil e eclesiástico, cuja distinção, já realizada em plena idade média, recebeu os encômios do insuspeito Augusto Comte.

Distinção entre os dois poderes não implica, todavia, a separação entre êles. Daí, além do disposto na constituição, art. 141, parágrafos $7 .^{\circ}$ e $8 .^{\circ}$ (o estado assegura o livre exercício dos cultos religiosos; o estado reconhece a existência das associações religiosas; o estado aceita, para certos efeitos, a invocação de motivos religiosos); art. 163, parágrafo $10^{\circ}$ e $2 .^{\circ}$ (reconhecimento do casamento religioso para lhe dar efeitos civis), além de vários dispositivos constitucionais - dizíamos — em que se acentua tão sòmente a distinção entre os poderes civil e espiritual, temos, 
na constituição vigente, a afirmação clara e precisa: relativamente aos dois referidos poderes deve haver a "colaboração recíproca em prol do interêsse coletivo" (art. 31, III).

Permite a constituição que o estado institua e pague capelães para as fôrças armadas, para escolas públicas com internato, para hospitais, manicômios, penitenciárias e prisões (art. 141, parágrafo $90^{\circ}$ ); manda respeitar o dia do Senhor e os dias santos de guarda (art. 157, VI); isenta de impostos as igrejas e capelas (art. $31, \mathrm{~B}$ ) ; inclui o ensino da religião entre as matérias assinaladas no horário das escolas oficiais (art. 168, V).

2. O conhecedor dos escritos de Rui Barbosa está bem a par de como a respeito das relações entre a igreja e o estado êle repetia a mesma advertência que costumava fazer ao comentar, em outras partes, o texto da carta de 1891: a fonte do nosso regime nem é o direito positivo nem a teoria dos franceses, mas a constituição e a doutrina norte-americana.

A miúde Rur repisou a afirmativa. Recordemos a sua lição, em três oportunidades, deixando em silêncio mais de uma dezena de repetições invariáveis: "A liberdade religiosa não é atéia, antes é profundamente cristã, essencialmente cristã, como os americanos, nosso modêlo, sempre a entenderam" (Senado federal, sessão de 21 de julho de 1903).

Escreveu em duas outras oportunidades ainda mais solenes: "No que toca às relações entre o estado e os cultos, o Partido republicano liberal é, igualmente, pelas idéias exaradas na plataforma de 1910. A constituição brasileira de 1891 estabeleceu a liberdade religiosa à americana, a liberdade religiosa como nos Estados Unidos".

"A prática nos Estados Unidos, a prática americana, pois, tem de ser, necessàriamente, o nosso modêlo na interpretação da nossa lei nacional quanto às relações entre o poder público e as diferentes confissões que o nosso regime, isento do espírito sectário, irreligioso e ateu, não 
considera inimigas, mas úteis colaboradoras na educação moral e cívica do povo" (Programa do Partido Republicano Liberal).

3. Nos Estados Unidos da América do Norte, além dos capelães criados para as mesmas instituições mencionadas na constituição brasileira, existem ainda, a mais, o capelão do senado e o da câmara dos deputados, os quais abrem com preces as sessões do congresso nacional; em cada prisão há um exemplar da Bíblia e, mais que isto, há também edições oficiais da Bíblia; permitem os Estados Unidos, nas escolas oficiais, a leitura da Bíblia, o canto de hino religioso e a reza do Padre Nosso ou de outra prece, na abertura dos trabalhos escolares.

As leis americanas reconhecem o cristianismo.

Fato curioso refere o protestante Philip Schaff, antigo mestre do Seminário teológico de Nova Iorque: votações de crédito, "com escôpo sectário (sic), no legislativo da cidade de Nova Iorque, em benefício dos católicos romanos, devido à influência do grande número de eleitores irlandeses".

É da referida autoridade um estudo sôbre "Igreja e estado nos Estados Unidos ou a idéia americana da liberdade religiosa e os seus efeitos práticos".

Dêle extraímos o seguinte: "As instituições democráticas, nas mãos de uma nação virtuosa e temente a Deus, são as melhores do mundo; nas mãos, porém, de povo corrupto e irreligioso são, de tôdas, as piores, constituem as mais eficazes armas de destruição. $O$ povo desprezado pode insurgir-se contra o tirano cruel; mas quem haverá de insurgir-se contra a tirania do povo, que possúi as urnas eleitorais e o inteiro mecanismo do governo? Reside aqui o nosso grande perigo, que cresce de dia para dia. - O cristianismo é o fator mais poderoso da nossa sociedade, é a pedra angular das nossas instituições".

Também lá, na grande democracia americana, a incredulidade e o sectarismo insurgiram-se contra a colaboração entre o estado e a igreja. Fundou-se até, em fins 
do século passado, uma "Liga" para defesa do liberalismo. Em petição de numerosos ítens, o quinto era assim redigido: "Pedimos que cessem inteiramente todos os auxílios a festividades e datas religiosas, por parte do presidente dos Estados Unidos e dos governos dos demais estados".

4. Convém explicar, a fim de prevenir possível objeção dos menos conhecedores do assunto, que a questão escolar, nos Estados Unidos da América do Norte, é totalmente diversa da que temos no Brasil.

Lá, em face da multiplicidade dos grupos religiosos, desde cedo a preferência foi para a escola pública, pois as confissões que contassem com poucos fiéis não possuiam elementos para manter escolas próprias. $O$ governo, em princípio, não subvenciona a escola particular.

Agora, por exemplo, se discute sôbre tal auxílio e precisamente vêm mencionadas as escolas religiosas. Basta saber que os principais adversários do auxílio público são entidades confissionais, para logo se aquilatar do pavor que as invade, diante da perspectiva de ingerência do estado no âmbito particular. Cairia por terra tôda a longa tradição de autonomia.

Bem outro é o nosso sistema (e a nossa tradição), quer público, quer das igrejas, cuja estrutura econômica é carecente de base, não, repousa em nenhuma disciplina sólida, como o dízimo, a saber, contribuem os fiéis dos cultos em geral com a décima parte do seu ganho, nos Estados Unidos; aqui, com esmolas!

No Brasil, as igrejas vivem de óbulos e os pais, que pagam taxas em escolas religiosas, já contribuem para os impostos com que o poder público mantém as escolas públicas.

5. O presente projeto de lei, longe de infringir a proibição constitucional de subvencionar cultos religiosos (artigo 31, II) e a de ter relação de aliança ou dependência com a igreja (idem, III), realiza o disposto na lei 
fundamental, quando prescreve a "colaboração recíproca" entre a igreja e o estado, "em prol do interêsse coletivo" (ibidem, in fine).

O interêsse público está a exigir, cada vez mais, a cristianização do nosso povo. O estado, em nossos dias, multiplicou as suas funções, mesmo para preencher satisfatòriamente a sua finalidade. Ora, a magnitude de tal programa conduz fàcilmente ao totalitarismo, ao absolutismo, ao panestatismo. Importa, a bem do regime democrático, não restringir danosamente o objetivo do estado, porém afirmar os direitos da pessoa humana, a liberdade de consciência, todos os demais direitos e deveres humanos e civis proclamados pela religião cristã. Foi a religião de Jesus Cristo que libertou o mundo, tanto assim que até o seu aparecimento o que havia era a hegemonia absoluta do poder público, situação em que se encontram ainda os povos que nunca conheceram ou abandonaram a religião de Cristo.

Isto é o que divisou o legislador constituinte, guiado pela história, ou seja pela experiência política, conduzido pelos grandes mestres, alguns dos quais, como Rui, nem sempre pensaram assim, é certo, mas renderam-se à evidência da verdade e ao reconhecimento do bem público.

Entendeu o nosso legislador que religião não é assunto puramente individual, que Deus e o seu culto não podem ser proscritos da vida do estado e, daí, ordenar a colaboração recíproca, quando o exija o interêsse coletivo. 0 que veda a constituição é que o culto seja subvencionado. $\mathrm{E}$ que haja aliança entre igreja e estado.

6. Em 1950, tivemos oportunidade de ver acolhida esta única e legítima interpretação da constituição federal de 1946, art. 31, II e III, pela comissão de constituição e justiça da câmara dos deputados, da qual fazíamos parte, na companhia de notáveis juristas e a seguir, por todo o congresso nacional, que converteu em lei o projeto de concessão de auxílio em dinheiro para o congresso eucarístico paroquial de Barbalha, no estado do Ceará. 
Tanto na esfera federal, quanto na estadual e municipal, tem sido praticada aludida doutrina, reconhecida pelos três poderes nacionais e regionais como sendo a legítima interpretação do texto constitucional. $O$ mais é facciosismo, sectarismo e ódio à religião, por parte dos que a desejam arredada da vida pública, ou seja, dos assuntos do povo.

Eis o que escrevemos, então, sôbre o caso particular de auxílio, com dinheiros públicos, a congressos encarísticos :

O projeto, concedendo auxílio à realização de congresso eucarístico, não manda pagar o culto público ao Santíssimo Sacramento, mas irá contribuir para o transporte e hospedagem das pessoas que a êle vão concorrer, para o enfeite e decoração da cidade e outros serviços de colaboração do estado com a igreja, "em prol do interêsse coletivo". Se o principal em tais certames religiosos é o culto público e a oração, não se pode esquecer que constituem também verdadeiros comícios de pregação moral e cívica.

Por tal forma o interêsse coletivo enlaça a igreja e o estado, em diversas situações, que o temor da quebra de suposta neutralidade absoluta há-de levar à não-colaboração entre os dois poderes, esta sim, em evidente desobediência ao preceito do art. 31, III, "in fine", que obriga o estado a colaborar com a religião, por exigência do interêsse coletivo.

7 No presente caso, é também evidente que se não cuida de subvencionar culto, nem de aliar-se à igreja. $O$ estado está "colaborando a prol do interêsse coletivo", como diz claramente a constituição federal, e colaborando com a igreja, como manda a lei principal.

Vejamos. Cogita-se de auxílio ao Seminário diocesano de São Pio X. Tanto faz ser a quantia pequena ou grande, entregue duma vez ou em anos sucessivos.

Há aí interesse coletivo? 
Se todos os alunos saíssem sacerdotes, ao cabo de estudo que é de longos anos, lucraria o município com o grande número de novos dirigentes sociais, de homens de cultura e virtude que, com a religião, iriam contribuir para a formação do coração e do caráter do povo, para a elevação e felicidade da família.

Mas a verdade, entretanto, não é esta, pois é certo que tão só dez por cento dos seminaristas chegam ao sacerdócio.

Já então se verifica que o seminário é casa de ensino para o povo em geral. É curioso que se destinando precìpuamente a formar sacerdotes, na realidade o que faz, em percentagem de noventa por cento, é educar e instruir os filhos do povo.

Ora, no Brasil, em que é espantoso o índice de analfabetos e em que é muito reduzido o número dos que conseguem fazer o curso secundário, saudamos com prazer os seminários menores diocesanos, que, com probidade e eficiência, produzem os assinalados frutos, alfabetizam e dão instrução secundária.

Quanto gastariam os poderes públicos para ocorrer às despesas com escolas primárias e secundárias para tão elevado número de jovens, como os que, neste momento, frequentam os bancos dos seminários? E, ainda mais, em regime de internato? Mais ainda, cêrca de metade recebendo de graça tudo, até roupas, sapatos e livros!?

8. Sem qualquer sombra de dúvida, é constitucional o projeto. E busca o interesse público. E é oportuno, máxime nesta época de invasão daninha do mais grosseiro materialismo. 